\title{
Non-Destructive Testing Methods as a Main ToOL Supporting EfFective WASTe Management IN Construction Processes
}

\begin{abstract}
J. JASKOWSKA-LEMAŃSKA ${ }^{1}$, J. SAGAN ${ }^{2}$
Construction and demolition (C\&D) waste management should be accordance with the waste management hierarchy. In practice, C\&D waste are often downcycling. It is the result of many factors, including lack of awareness about the value inherent in waste. The paper presents analysis of the adaptability of non-destructive testing (NDT) methods for technical assessment of waste properties. As part of the work, non-destructive testing methods were described and classified in accordance with material and the features they enable testing. The publication presents examples of the use of NDT in the recovery of building materials during construction projects, in the field of influence of technical information of waste on the way it is managed. Finally, a scheme of waste management process during the renovation of an object with the application of NDT methods was presented.
\end{abstract}

Keywords: Non-destructive testing methods, CLSC management, circular economy, C\&D waste

\section{INTRODUCTION}

Construction and demolition (C\&D) waste management should be based on the waste management hierarchy, and its observance can bring environmental and financial benefits [1], [2]. The assumptions of the circular economy are opposed to the linear economy paradigms, for waste is

\footnotetext{
${ }^{1}$ MSc., Eng., AGH University of Science and Technology, Department of Geomechanics, Civil Engineering and Geotechnics, Av. Mickiewicza 30, 30-059 Cracow, Poland, e-mail: lemanska@agh.edu.pl, ORCID: 0000-0003-31160448

${ }^{2}$ PhD., Eng., AGH University of Science and Technology, Department of Geomechanics, Civil Engineering and Geotechnics, Av. Mickiewicza 30, 30-059 Cracow, Poland, e-mail: czajaj@agh.edu.pl, ORCID: 0000-0003-41376613
} 
treated as a raw material. Reconstruction of the classical supply chain to the closed system (circulation) is considered to be an effective approach to reduce costs while taking into account the impact on the environment and consumers' requirements [3].

Despite the positive experience in closing supply chains by the manufacturing industry, in the construction sector there are much greater difficulties [4], [5]. Among the barriers, the interdisciplinary nature of activities related to recovery is emphasized, and so is the wide range of variables affecting the flow of returnable streams [6]. In construction, the recovery of C\&D waste should take place in accordance with the principles and technical standards applicable in construction as well as legal regulations [7]. As a result, masonry and concrete elements are processed into the form of debris, steel elements are scrapped, and wood elements are used for energy recovery. An alternative to such a scenario is to examine the physical and mechanical features of building elements (often before deconstruction) and then, if the results are promising, extract the highest value inherent in the waste.

The article contains a literature review of NDT methods (with pros and cons) used in assessing technical parameters of construction waste (Section 2). The area of consideration includes wood, steel, concrete and ceramic waste. The article also presents examples of using nondestructive examinations to recover C\&D waste (Section 3). As a result, a procedure scheme of the waste management process during the renovation of the object with the application of NDT methods was developed (Section 4).

\section{REVIEW OF NDT METHODS}

Non-destructive and semi-destructive tests are practical methods used to determine the characteristics and parameters of structural elements of buildings. The advantage of both methods is the ability to conduct tests or the entire element, with no significant interference in the structure of the tested material. Although semi-destructive tests cause small cavities, their sizes do not significantly affect the technical parameters of the element, and the resulting damage can be easily masked. Within the NDT methods the following can be distinguished: organoleptic tests (macroscopic evaluation) and all technical tests based on acoustic, electrical, radiological, or electromagnetic methods [8], [9]. Within the scope of non-destructive and semi-nondestructive testing, there are also tests based on various types of mechanical impact, such as the measurement of pulling force and of the depth of an induced cavity [10]-[12]. The basic features of the building elements to be assessed are as follows: the shape and dimensions of the element, material 
properties, the location and extent of damage, material corrosion including microbiological evaluation.

Table 1 gives an overview of the non-destructive and semi-destructive test methods that can be used in the assessment of building elements intended for disposal. The methods are compiled for building materials such as steel, wood, concrete and ceramics. The following list is not a comprehensive list of existing methods. Advanced non-destructive testing methods with higher accuracy are more expensive and have limited mobility. For that reason, they are not included as dedicated methods for the recovery of construction waste. Rising NDT costs reduces the financial effectiveness of recovery.

Macroscopic evaluation is the simplest and low-budget test method, which allows for a preliminary assessment of the technical condition of construction elements, including their wear and tear as well as the changes caused by biological factors, microclimate and execution errors [13].

Table 1. Applicability of non-destructive and semi-destructive methods for assessment of the value

of construction waste

\begin{tabular}{|c|c|c|c|c|c|c|}
\hline \multirow{2}{*}{\multicolumn{2}{|c|}{ Features }} & \multirow{2}{*}{ Method } & \multicolumn{4}{|c|}{ Material } \\
\hline & & & Steel & Wood & Concrete & Ceramics \\
\hline \multicolumn{2}{|c|}{$\begin{array}{c}\text { Shape and dimensions of the } \\
\text { element }\end{array}$} & Macroscopic evaluation & + & + & + & + \\
\hline \multirow{5}{*}{$\begin{array}{l}\text { Mechanical } \\
\text { properties }\end{array}$} & \multirow{3}{*}{ Strength } & Sclerometric tests & + & $+/-$ & + & $+/-$ \\
\hline & & Uultrasonic method & + & $+/-$ & + & - \\
\hline & & Pulling force test & - & $+/-$ & + & $+/-$ \\
\hline & \multirow{2}{*}{$\begin{array}{l}\text { Modulus of } \\
\text { elasticity }\end{array}$} & Test load method & + & + & + & - \\
\hline & & Ultrasonic method & + & + & - & - \\
\hline \multirow{8}{*}{$\begin{array}{l}\text { Physical } \\
\text { properties }\end{array}$} & \multirow{4}{*}{ Density } & Direct measurement & $+/-$ & $+/-$ & $+/-$ & $+/-$ \\
\hline & & Ultrasonic methods & $+/-$ & $+/-$ & $+/-$ & $+/-$ \\
\hline & & Radiographic methods & $+/-$ & $+/-$ & $+/-$ & $+/-$ \\
\hline & & Trimming resistance test & - & + & - & - \\
\hline & Colour & Macroscopic evaluation & + & + & + & + \\
\hline & \multirow{3}{*}{ Humidity } & Chemical methods & - & - & + & + \\
\hline & & Electrical methods & - & + & + & + \\
\hline & & Thermographic method & - & + & + & + \\
\hline \multirow{5}{*}{\multicolumn{2}{|c|}{$\begin{array}{l}\text { Surface and internal defects of the } \\
\text { structure }\end{array}$}} & Macroscopic evaluation & + & + & + & + \\
\hline & & $\begin{array}{l}\text { Acoustic methods } \\
\text { (ultrasonic) }\end{array}$ & + & + & + & + \\
\hline & & Radiographic method & + & $+/-$ & $+/-$ & $+/-$ \\
\hline & & Trmming resistance test & - & + & - & - \\
\hline & & Thermographic method & + & + & + & + \\
\hline \multirow{3}{*}{ Corrosion } & Microbiological & $\begin{array}{l}\text { Macroscopic and } \\
\text { microscopic evaluation }\end{array}$ & - & + & $+/-$ & $+/-$ \\
\hline & \multirow[b]{2}{*}{ Chemical } & Macroscopic evaluation & + & - & $+/-$ & $+/-$ \\
\hline & & $\begin{array}{c}\text { Chemical and } \\
\text { electrochemical methods }\end{array}$ & + & - & + & + \\
\hline
\end{tabular}

+ well established; +/- limited applicability; - not applicable 
Organoleptic tests could be supported by optical tools, such as a Brinella magnifier, an endoscope, etc [14]. However, such an evaluation should not be treated as a stand-alone test method, due to a possible variability of structural parameters within the cross-section of the element, which may lead to incorrect evaluation. If the structure of the element changes unfavorably with the depth, the loadbearing capacity of the element can be overestimated and, as a consequence, can lead to failure or a building catastrophe. In the opposite situation, when the structure of the element changes favorably into the interior, the potential inherent in the element may not be exploited [15]. Therefore, in order to extract the maximum value embodied in the waste, the macroscopic evaluation should be supported by the methods of non-destructive and semi-destructive testing, including the evaluation of the mechanical properties.

The non-destructive method, which requires only simple geometrical measurements and enables the evaluation of the mechanical parameters of the element, is the test load method. This method consists of measuring the deflection under load. It is most commonly used for testing horizontal elements such as beams, floor slabs, etc. [16].

A popular and wide group of tests are methods based on the phenomenon of ultrasound wave propagation in the material. Such methods enable us to investigate the structural defects of the material such as cavities or cracks and indirectly (through correlations) to determine its density and mechanical properties [10], [17]. Ultrasonic testing of strength parameters is possible for steel and concrete [8], [18], [19] while for timber they are limited to the modulus of elasticity test [20]. Strength results obtained from independent ultrasound tests are characterized by a wide range of errors. For more precise results the findings should be calibrated by conducting destructive tests on elements belonging to the same series [21]. In turn, defectoscopy using ultrasonic methods can be performed for all presented materials; however, despite the short time of measurements, it is necessary to emphasize the complex process of interpretation of the results [22], [23]. Only hightech equipment ensures automation of the interpretation process.

Another group of common and simple testing methods are the measurements of surface hardness, represented by the rebound rate, which is correlated to the material strength. For materials with the low variability of material parameters in assortment grades (such as steel or concrete), reflectance measurement methods are widely used because of their simplicity, efficiency and easy interpretation [24]. In the case of masonry ceramic elements, such methods are more often used to assess the homogeneity of materials than to determine their mechanical properties [25]. As in ultrasonic tests, in order to obtain more precise results, additional destructive laboratory tests need to be performed. On the other hand, testing wood hardness is more difficult to interpret and less 
reliable than testing isotropic materials. Difficulties are caused by the variability of the mechanical parameters of timber, such as timber defects, moisture content or the direction of testing in relation to the anatomical structure of the wood [26]. Nevertheless, sclerometer measurements for wood, hardness measured by an indenter, are becoming increasingly common, because they measure the density of the material, which is valuable information to estimate the load-bearing capacity of a timber. However, hardness measured by an indenter is a semi-destructive method that results in small cavities of about $1 \mathrm{~mm}$ in diameter and up to $30 \mathrm{~mm}$ in depth; therefore, it is necessary to complete the test by repairing the cavities [27].

A similar penetration method to examination wood material features, mainly density, is drilling resistance testing. Such a test records the force that a thin drill needs to penetrate the element at a constant speed. The depth of penetration depends on the device, typically $40-50 \mathrm{~cm}$, which makes it possible to test most or even the whole cross-section; therefore, it gives more reliable results than surface tests [28], [29].

Alternative semi-destructive methods are based on the measurement of pull-out force. These methods are mainly used in determining the strength characteristics of concrete, less often of ceramic elements and timber. They, however, cause significant damages, thus, have not gained much popularity.

The applicability of ultrasonic, sclerometric and penetration methods may result is a significantly higher accuracy if correlation curves (a relation between DT and NDT results) are developed for a specific type of material e.g., bricks from a particular period and region [21]. Most of the presented non-destructive and semi-destructive methods can be successfully used to verify the improvement of parameters after repair or maintenance operations [30].

The most accurate methods for assessing the homogeneity and, thus, density and continuity of material are radiographic methods: X-ray and gamma defectoscopy. The results of radiographic methods may be two-dimensional (2D) or three-dimensional (3D) images, depending on the used technique. Tests can precisely define the location, dimensions and the sizes of defects; as well as, indirectly, determine the density of the tested material [31]-[33]. In practice nowadays, these methods are most often used for testing joints of steel elements [34]. Due to the high costs of in-situ radiographic examinations of any other materials such as wood, concrete or masonry elements, its use is justified for valuable historical elements. Radiographic examination usually requires complete access to the element, which is not always possible or possible with additional costs.

A significant physical feature that determines the strength parameters of a material and its suitability for further use is the moisture content. Non-destructive moisture testing can be carried 
out using electrical methods and thermographic dependencies, whereas semi-destructive chemical methods require taking small samples.

The method successfully used to locate excessive humidity is thermovision. Infrared thermography is a process of medium-infrared imaging, enabling registration of thermal radiation emitted by objects and, thus, provide an accurate temperature measurement. This method is extremely useful in the study of assessing a large quantity of material and of finding location with excessive or variable humidity [35]. The active thermography method can be used to visualize invisible discontinuities, e.g., cracks and scratches [36], [37].

Electrical methods are most commonly used to determine moisture content; they are based on the measuring of electrical resistance or dielectric constant. These properties change with the moisture content of the material, and devices have built-in correlation functions. The method is widely available, does not require special experience and is relatively cheap. Test errors may result from an incorrectly predefined material density as well as from the type of the contact surface [38]. Chemical methods are most commonly used for concrete and ceramics and one of the most popular is the carbide method, which uses calcium carbide decomposition in water. As a result of the reaction, acetylene is produced, which causes an increase of pressure in the container, the level of which is a function of humidity.

Another methods determine the degree of chemical corrosion of materials. Apart from macroscopic evaluation, they usually test the concentration of chemical components causing the corrosion process. Chemical methods are also combined with electrical and other physical phenomena [39]. Determining the degree of chemical corrosion for masonry and concrete elements usually requires taking appropriate core samples. The level of chemical corrosion in steel elements is determined using penetration [8] and magnetic methods [40]. The penetration method uses the phenomenon of capillarity and is relatively inexpensive and does not require special skills; however, it is time-consuming, while the magnetic method performs tests quickly, but requires a very advanced apparatus.

The presented set of methods contain an important scientific achievements which have been popularized, however, attention should be paid also to the further development of non-destructive testing, towards new tools and methodological approaches, e.g.[41], [42]. 


\section{Examples of APPLiCAtion Of NDT in Construction Processes}

Non-destructive testing is successfully used in the technical assessment of building components, as evidenced by many literature examples and observed in construction practice [13], [43]-[49]. Also, the application of non-destructive tests in the recovery of building elements in the renovation of the Gorzanów Palace was published [50]. Currently, after 7 years of the authors' collaboration with the Gorzanow Palace Foundation, the effects of the approach used in practice can be fully discussed.

Due to the limitation of the technical condition assessment to the organoleptic method during renovation works, several failures in the building occurred. One of them is the failure of the roof structure (Fig. 1), resulting from excessive load on the reused roof framing caused by new tiles of higher unit weight. To support revalorization works, non-destructive tests have been implemented to increase the effectiveness of the evaluation.

An example of the recovery of structural timber beams is nine-meter ceiling beams recovered, which had degraded support zones. The technical condition of the facility required deconstruction

( Fig. 2a). Timber beams were stored (Fig. 2b), cleaned and cut in the degradation zones.

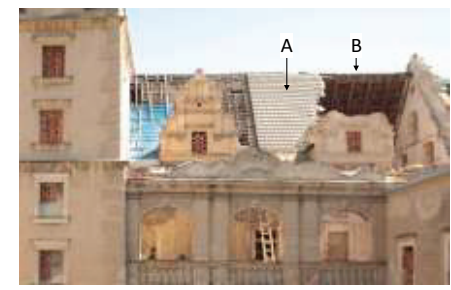

Fig. 1. Roof structure failure in the Gorzanow Palace

Conducting organoleptic and non-destructive tests of mechanical parameters led to the assessment of the strength parameters of wood (Fig. 2c), which together with the information about the crosssection of the elements enabled the assessment of their load-bearing capacity (Fig. 2d). Finally, the beams were built into a shorter span ceiling (Fig. 2e). The final effect of material recovery (in one of the completed rooms) is presented in Fig. $2 \mathrm{f}$. 

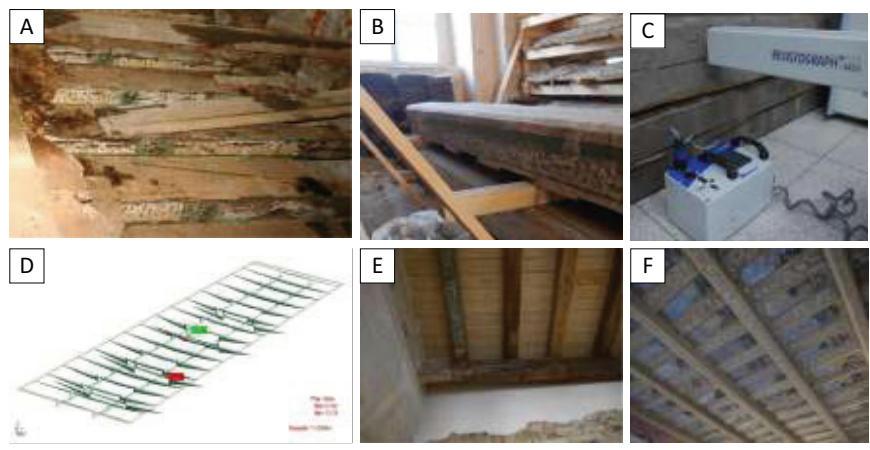

Fig. 2. Recovery of timber structural beams

During the revalorization of the Palace, the recovery of ceramic materials was also undertaken. Ceramic materials obtained from demolition processes were brick and tile. Such materials are usually crushed and used to strengthen the soil near the building for various purposes. Waste material was selectively collected, stored and subjected to NDT. Performed non-destructive tests resulted in the recovery of a higher value of brick: nearly $85 \%$ of the waste material was fit for embedding into the structure and only $15 \%$ was assigned for non-structural purposes. The historical value of the elements favoured the idea of reusing the material for revalorization purpose (in order to preserve its authenticity); thus, part of waste intended for non-structural purpose were used for floor coverings.

The current experience of the authors refers to ceramic and wooden materials. Examples of the applicability of NDT methods in steel structures can be found in another paper [51].

\section{CONCEPTS OF USING NDT METHOd IN WASTE MANAGEMENT PROCESS}

Years of experience in renovation, allowed to create a scheme of the waste management process, with application of NDT during the renovation (Fig. 3). The elements and systems of the building which no longer meet the technical or functional requirements are replaced. Nondestructive testing methods can be implemented in terms of both technical parameters and physical properties of the elements. A process starts by an organoleptic evaluation of the elements of an object. If the technical condition is in doubt, then, an assessment of the technical condition must be provided. At a subsequent stage, organoleptic visions with appropriate technical studies (Table 1) reduce the risk of losing the benefits inherent in the element which appeared to meet the technical and functional requirements. Sometimes, an element may only require surface treatment 
(refurbishment or maintenance) for further operation. In this way, NDT supports the first postulate in the waste management hierarchy, i.e. the prevention of waste generation while limiting the risk of construction failures. If a tested element does not meet the technical requirements based on its wear and strength parameters, strengthening them as well as a replacement may be provided. In a situation where a building element is decomposed, it can be used for other purposes (within renovation area) or sold as a secondary product.

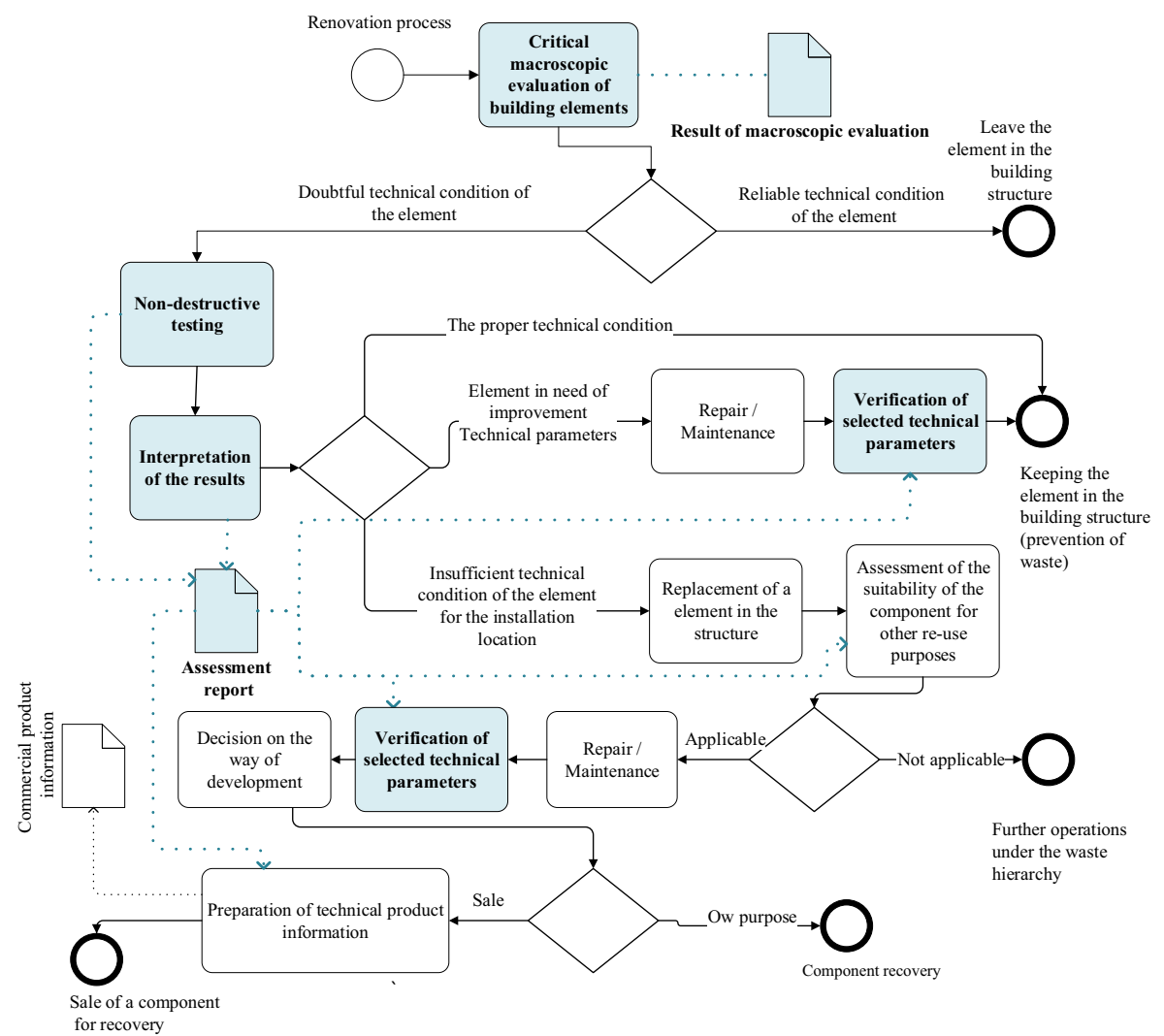

Fig. 3. Scheme of the waste management process during the renovation of an object with the application of

NDT methods

Based on NDT results, it is possible to prepare commercial technical information about the secondary product. This information can be given in the form of technical parameters or in the form of raw non-destructive test results, transferring the process of interpretation of the results to the purchaser. In this way, the seller can transfer the risk, thus, avoiding responsibility for the 
declared quality of the product. Such an attitude, however, entails the risk of a missed opportunity resulting from the lack of demand for a product without a declaration of technical parameters.

\section{SUMMARY AND CONCLUSIONS}

The recovery of construction waste is now common practice, but the decision-making process of waste management is not supported by sufficient tools that enable the objective assessment of technical parameters of waste; thus, waste is often downcycling. At the stage of planning the renovation of construction works, it is reasonable to consider various implementation scenarios [52], one of the selection criteria may be the waste recovery rate. The presented approach to construction waste management has the following advantages, it:

- ensures waste management in accordance with the waste management hierarchy;

- minimizes the risk associated with the occurrence of failure resulting from incorrect estimation of technical parameters of building elements,

- enables the sale of a recovered element with assurance of its quality confirmed by NDT result,

- can be carried out on site, making sales possible directly from the construction site, and reducing the costs and emissions associated with additional transport, and

- allows the authenticity of historic buildings to be preserved.

Thereby, the approach helps eliminate the main barriers related to waste recovery in the construction industry, such as convincing consumers about the low quality of recycled products [53], [54] and uncertainty about the results of the recovery [48], [53], [55]. Due to the civilization's aspiration to perform circular economy, the development of NDT methods and tools for the determination of technical parameters of waste is forecasted.

\section{REFERENCES}

[1] A. Sobotka and J. Sagan, "Cost-saving Environmental Activities on Construction Site - Cost Efficiency of Waste Management: Case Study," Procedia Eng., vol. 161, no. Supplement C, pp. 388-393, 2016.

[2] V. Tam, "Economic comparison of concrete recycling: A case study approach," Resour. Conserv. Recycl., vol. 52, pp. 821-828, 2008.

[3] B. Tundys, "Zielony łańcuch dostaw w gospodarce o okrężnym obiegu - założenia , relacje , implikacje « Green supply chain in circular economy - assumptions , relations , implications »," 2015.

[4] S. Sinha, R. Shankar, and P. Taneerananon, "Modelling and case study of reverse logistics for construction aggregates," International journal of logistics systems and management, vol. 6, no. 1. Inderscience, Olney, pp. 39-59, 2010.

[5] W. M. Shakantu and F. A. Emuze, "Assessing reverse logistics in South African construction," in Proceedings for the 20th annual conference of the international group for lean construction, 2012, pp. 18-20.

[6] C. Carter and L. Ellram, "Reverse logistics: A review of the literature and framework for future investigation," J. Bus. Logist., vol. 19, no. 1, pp. 85-102, 1998. 
[7] A. Sobotka and J. Czaja, "Analysis of the Factors Stimulating and Conditioning Application of Reverse Logistics in Construction,” Procedia Eng., vol. 122, no. Supplement C, pp. 11-18, 2015.

[8] S. K. Dwivedi, M. Vishwakarma, and P. A. Soni, "Advances and Researches on Non Destructive Testing: A Review," Mater. Today Proc., vol. 5, no. 2, pp. 3690-3698, 2018.

[9] S. Gholizadeh, "A review of non-destructive testing methods of composite materials," Procedia Struct. Integr., vol. 1, pp. 50-57, 2016.

[10] J. Hoła, J. Bień, L. Sadowski, and K. Schabowicz, "Non-destructive and semi-destructive diagnostics of concrete structures in assessment of their durability," Bull. Polish Acad. Sci. Tech. Sci., vol. 63, no. 1, pp. 8796, 2015 .

[11] M. Kloiber, M. Drdácký, J. S. Machado, M. Piazza, and N. Yamaguchi, "Prediction of mechanical properties by means of semi-destructive methods: A review," Constr. Build. Mater., vol. 101, pp. 1215-1234, 2015.

[12] H. J. Schindler, "On quasi-non-destructive strength and toughness testing of elastic-plastic materials," Int. J. Solids Struct., vol. 42, no. 2, pp. 717-725, 2005.

[13] G. Kilic, "Using advanced NDT for historic buildings: Towards an integrated multidisciplinary health assessment strategy," J. Cult. Herit., vol. 16, no. 4, pp. 526-535, 2015.

[14] A. Borri, M. Corradi, A. De Maria, and R. Sisti, "Calibration of a visual method for the analysis of the mechanical properties of historic masonry," Procedia Struct. Integr., vol. 11, pp. 418-427, 2018.

[15] A. S. H. Makhlouf and A. Mahmood, Handbook of Materials Failure Analysis. Butterworth-Heinemann, 2018.

[16] L. Runkiewicz and J. Sieczkowski, "Stosowanie obciążeń próbnych do oceny stanu technicznego budynków," Przegląd Bud., vol. 7-8, pp. 39-44, 2015.

[17] J. Hoła and L. Runkiewicz, "Methods and diagnostic techniques used to analyse the technical state of reinforced concrete structures,” Struct. Environ., vol. 10, pp. 309-337, 2018.

[18] N. Pereira and X. Romão, "Assessing concrete strength variability in existing structures based on the results of NDTs,” Constr. Build. Mater., vol. 173, pp. 786-800, 2018.

[19] D. Stegemann, B. Raj, and A. K. Bhaduri, "NDT for Analysis of Microstructures and Mechanical Properties of Metallic Materials," in Reference Module in Materials Science and Materials Engineering, Elsevier, 2016.

[20] A. Ettelaei, M. Layeghi, H. Zarea Hosseinabadi, and G. Ebrahimi, "Prediction of modulus of elasticity of poplar wood using ultrasonic technique by applying empirical correction factors," Meas. J. Int. Meas. Confed., vol. 135, pp. 392-399, 2019.

[21] K. Ali-Benyahia, Z. M. Sbartaï, D. Breysse, M. Ghrici, and S. Kenai, "Improvement of nondestructive assessment of on-site concrete strength: Influence of the selection process of cores location on the assessment quality for single and combined NDT techniques," Constr. Build. Mater., vol. 195, pp. 613-622, 2019.

[22] V. V. Koshovyi, E. V. Kryvin, and I. M. Romanyshyn, "Ultrasonic computer romography in nondestructive testing and technical diagnostics," Mater. Sci., vol. 33, no. 5, pp. 31-41, 1997.

[23] N. Shetty et al., "Quantification of progressive structural integrity loss in masonry with Acoustic Emissionbased damage classification," Constr. Build. Mater., vol. 194, pp. 192-204, 2019.

[24] R. B. Clough, S. C. Webb, and R. W. Armstrong, "Dynamic hardness measurements using a dropped ball: With application to 1018 steel," Mater. Sci. Eng. A, vol. 360, no. 1-2, pp. 396-407, 2003.

[25] J. Galvão, I. Flores-Colen, J. de Brito, and M. R. Veiga, "Variability of in-situ testing on rendered walls in natural ageing conditions - Rebound hammer and ultrasound techniques," Constr. Build. Mater., vol. 170, pp. $167-181,2018$.

[26] J. Jaskowska-Lemańska and D. Wałach, "Impact of The Direction of Non-Destructive Test with Respect to The Annual Growth Rings of Pine Wood,” vol. 161, pp. 925-930, 2016.

[27] T. Tannert et al., "In situ assessment of structural timber using semi-destructive techniques," Mater. Struct., vol. 47, no. 5, pp. 767-785, 2014.

[28] T. Nowak, J. Jasieńko, and K. Hamrol-Bielecka, "In situ assessment of structural timber using the resistance drilling method - Evaluation of usefulness," Constr. Build. Mater., vol. 102, pp. 403-415, 2016.

[29] M. Kloiber, J. Tippner, and J. Hrivnák, "Mechanical properties of wood examined by semi-destructive devices," Mater. Struct., vol. 47, pp. 199-212, 2014.

[30] D. F. Henriques and A. S. Neves, "Semi-destructive in situ tests as support to the assessment of a conservation process," Constr. Build. Mater., vol. 101, pp. 1253-1258, 2015.

[31] M. Cała et al., "Identification of Microstructural Properties of Shale by Combined Use of X-Ray Micro-CT and Nanoindentation Tests," Procedia Eng., vol. 191, pp. 735-743, 2017.

[32] N. Kardjilov, I. Manke, R. Woracek, A. Hilger, and J. Banhart, “Advances in neutron imaging,” Mater. Today, vol. 21, no. 6, pp. 652-672, 2018.

[33] K. Ostrowski et al., "The effect of the morphology of coarse aggregate on the properties of self-compacting high-performance fibre-reinforced concrete," Materials (Basel)., vol. 11, no. 8, 2018.

[34] R. F. Hamade and A. M. R. Baydoun, "Nondestructive detection of defects in friction stir welded lap joints using computed tomography," Mater. Des., vol. 162, pp. 10-23, 2019.

[35] E. Grinzato, P. G. Bison, and S. Marinetti, "Monitoring of ancient buildings by the thermal method," J. Cult. 
Herit., vol. 3, no. 1, pp. 21-29, 2002.

[36] S. Doshvarpassand, C. Wu, and X. Wang, "An overview of corrosion defect characterization using active infrared thermography," Infrared Phys. Technol., vol. 96, no. September 2018, pp. 366-389, 2019.

[37] V. P. Vavilov, "Modeling thermal NDT problems," Int. J. Heat Mass Transf., vol. 72, pp. 75-86, 2014.

[38] M. I. Martínez-Garrido, R. Fort, M. Gómez-Heras, J. Valles-Iriso, and M. J. Varas-Muriel, “A comprehensive study for moisture control in cultural heritage using non-destructive techniques," J. Appl. Geophys., vol. 155, pp. 36-52, 2018.

[39] Y. Lietai, Techniques for Corrosion Monitoring. Cambridge: Woodhead Publishing Limited, 2008.

[40] Z. D. Wang, Y. Gu, and Y. S. Wang, "A review of three magnetic NDT technologies," J. Magn. Magn. Mater., vol. 324, no. 4, pp. 382-388, 2012.

[41] Ł. Sadowski and T. G. Mathia, "Multi-scale metrology of concrete surface morphology: Fundamentals and specificity," Constr. Build. Mater., vol. 113, pp. 613-621, 2016.

[42] J. Szymanowski, "Evaluation of the Adhesion between Overlays and Substrates in Concrete Floors: Literature Survey, Recent Non-Destructive and Semi-Destructive Testing Methods, and Research Gaps," Buildings, vol. 9, p. 203, 2019.

[43] L. Capozzoli and E. Rizzo, "Combined NDT techniques in civil engineering applications: Laboratory and real test," Constr. Build. Mater., vol. 154, pp. 1139-1150, 2017.

[44] G. Cardani and L. Binda, "Guidelines for the Evaluation of the Load-Bearing Masonry Quality in Built Heritage," in Research for Development, 2015, pp. 127-139.

[45] G. Kilic, "Integrated health assessment strategy using NDT for reinforced concrete bridges," NDT E Int., vol. 61, pp. 80-94, 2014.

[46] J. Hoła and K. Schabowicz, "State-of-the-art non-destructive methods for diagnostic testing of building structures - anticipated development trends," Arch. Civ. Mech. Eng., vol. 10, no. 3, pp. 5-18, 2010.

[47] A. T. Smith, C. R. A. Schneider, C. R. Bird, and M. Wall, "Use of non-destructive testing for engineering critical assessment: Background to the advice given in BS 7910:2013," Int. J. Press. Vessel. Pip., vol. 169, no. November 2018, pp. 153-159, 2019.

[48] J. Jaskowska-Lemańska, D. Wałach, and J. Sagan, "Technical Condition Assessment of Historical Buildings: Flowchart Development," Infrastruct. Ecol. Rural AREAS, vol. 4, pp. 1755-1768, 2016.

[49] E. Radziszewska-Zielina and G. Śladowski, "Assessment of the Conditions that Determine the Reclaiming of Stone Materials and their Use in the Revalorisation of Historical Buildings," MATEC Web Conf., vol. 117, pp. $0-7,2017$.

[50] J. Jaskowska-Lemańska and J. Czaja, "Non-Destructive Testing Methods of Building Structures as Part of Reverse Logistics on the Example of Gorzanów Palace Renovation,” Logistyka, vol. 4, pp. 4359-4371, 2014.

[51] M. Fujita and T. Masuda, "Application of Various NDT Methods for the Evaluation of Building Steel Structures for Reuse,” Materials (Basel)., vol. 7, no. 10, pp. 7130-7144, 2014.

[52] E. Radziszewska-Zielina and G. Śladowski, "Fuzzy Inference System Assisting the Choice of a Variant of Adaptation of a Historical Building,” Int. J. Contemp. Manag., vol. 2015, no. Issue 14(4).

[53] P. González-Torre, M. Álvarez, J. Sarkis, and B. Adenso-Díaz, "Barriers to the Implementation of Environmentally Oriented Reverse Logistics: Evidence from the Automotive Industry Sector,” Br. J. Manag., vol. 21, no. 4, pp. 889-904, 2010.

[54] F. Schultmann and N. Snuke, "Organisation of reverse logistics tasks in the construction industry," in SB07 Portugal: Sustainable Construction, Materials and Practices: Challenge of the Industry for the New Millenium, 2008 .

[55] B. Addis, Building with Reclaimed Components and Materials. London: Earthscan, 2006.

\section{LIST OF FIGURES AND TABLES:}

Fig. 1. Roof structure failure in the Gorzanow Palace

Rys. 1. Awaria konstrukcji dachu Pałacu w Gorzanowie

Fig. 2. Recovery of timber structural beams

Rys. 2. Odzysk konstrukcyjnych belek drewnianych

Fig. 3. Scheme of the waste management process during the renovation of an object with the application of NDT methods

Rys. 3. Schemat procesu gospodarki odpadami podczas remontu obiektu z zastosowaniem metod NDT

Tab. 1. Applicability of non-destructive and semi-destructive methods for assessment of the value of construction waste

Tab. 1. Możliwość zastosowania nieniszczących i semi-niszczących metod w ocenie parametrów technicznych odpadów budowlanych 


\section{BADANIA NIENISZCZĄCE JAKO GLÓWNE NARZĘDZIE WSPIERAJĄCE PROCES GOSPODAROWANIA ODPADAMI BUDOWLANYMI}

Keywords: badania nieniszczące, zamknięty łańcuch dostaw, ekonomia o obiegu zamkniętym, odpady budowlane

\section{SUMMARY:}

Gospodarka odpadami budowlanymi powinna odbywać się zgodnie z hierarchią postępowania z odpadami, a jej przestrzeganie może przynieść korzyści środowiskowe i finansowe [1], [2]. Prawidłowe gospodarowanie odpadami wymaga więc poprawnej oceny wartości odpadów (ich przydatności). Konstrukcje budowlane podlegają jednak procesom destrukcyjnym, których przebieg i przebieg są zróżnicowane i związane z szeregiem czynników, takich jak zmiany temperatury, wilgotność, występowanie obciążeń statycznych i dynamicznych oraz korozja chemiczna i biologiczna. Z tych powodów parametry techniczne produktu poddanego odzyskowi z reguły odbiegają od jakości produktu pierwotnego, stąd wymagają oceny. Brak prawidłowego oznaczenia parametrów mechanicznych materiału pochodzącego z odzysku a przeznaczonego na cele konstrukcyjne stwarza ryzyko wystąpienia awarii, co zniechęca do stosowania produktów pochodzących z recyklingu. Niepewność co do wyników odzysku jest jedną z głównych barier w stosowaniu materiałów pochodzących z recyklingu [28], [37], [39]. Inne bariery to opór organizacji [40] i trudność w przekonaniu konsumentów, że jakość produktów pochodzących z recyklingu jest właściwa.

Określenie fizycznych i mechanicznych właściwości odpadów może być skutecznie przeprowadzone przy użyciu badań nieniszczących i semi-niszczących (NDT), które obejmują narzędzia i metody badawcze. Badania nieniszczące i semi-niszczące są praktycznymi metodami służącymi do określania właściwości i parametrów elementów konstrukcyjnych budynków. Zaletą obu metod jest możliwość prowadzenia badań na całym elemencie, bez znaczącej ingerencji w strukturę badanego materiału. W ramach NDT można wyróżnić następujące metody: badania organoleptyczne (ocena makroskopowa) oraz wszystkie badania techniczne oparte na metodach akustycznych, elektrycznych, radiologicznych lub elektromagnetycznych. Podstawowe cechy ocenianych elementów budowlanych to: kształt i wymiary elementu; parametry mechaniczne, fizyczne i chemiczne; położenie i zakres uszkodzeń; stopień korozji chemicznej i mikrobiologicznej. W artykule przedstawiono przegląd metod badań nieniszczących i seminiszczących które mogą być stosowane w ocenie elementów budowlanych przeznaczonych do odzysku. Syntetyczne opracowanie sporządzono dla takich materiałów budowlanych jak stal, drewno, beton i ceramika.

Przedstawione w niniejszym opracowaniu praktyczne przykłady stosowania badań nieniszczących w ocenie odzyskiwanych elementów, potwierdzają przydatność metod NDT w gospodarce odpadami budowlanymi w celu odzyskania wyższej ich wartości. W oparciu o wieloletnie obserwacje, autorzy przedstawiają schemat gospodarowania odpadami budowlanymi z zastosowaniem metod NDT w obszarze robót remontowych (Rys.1). 


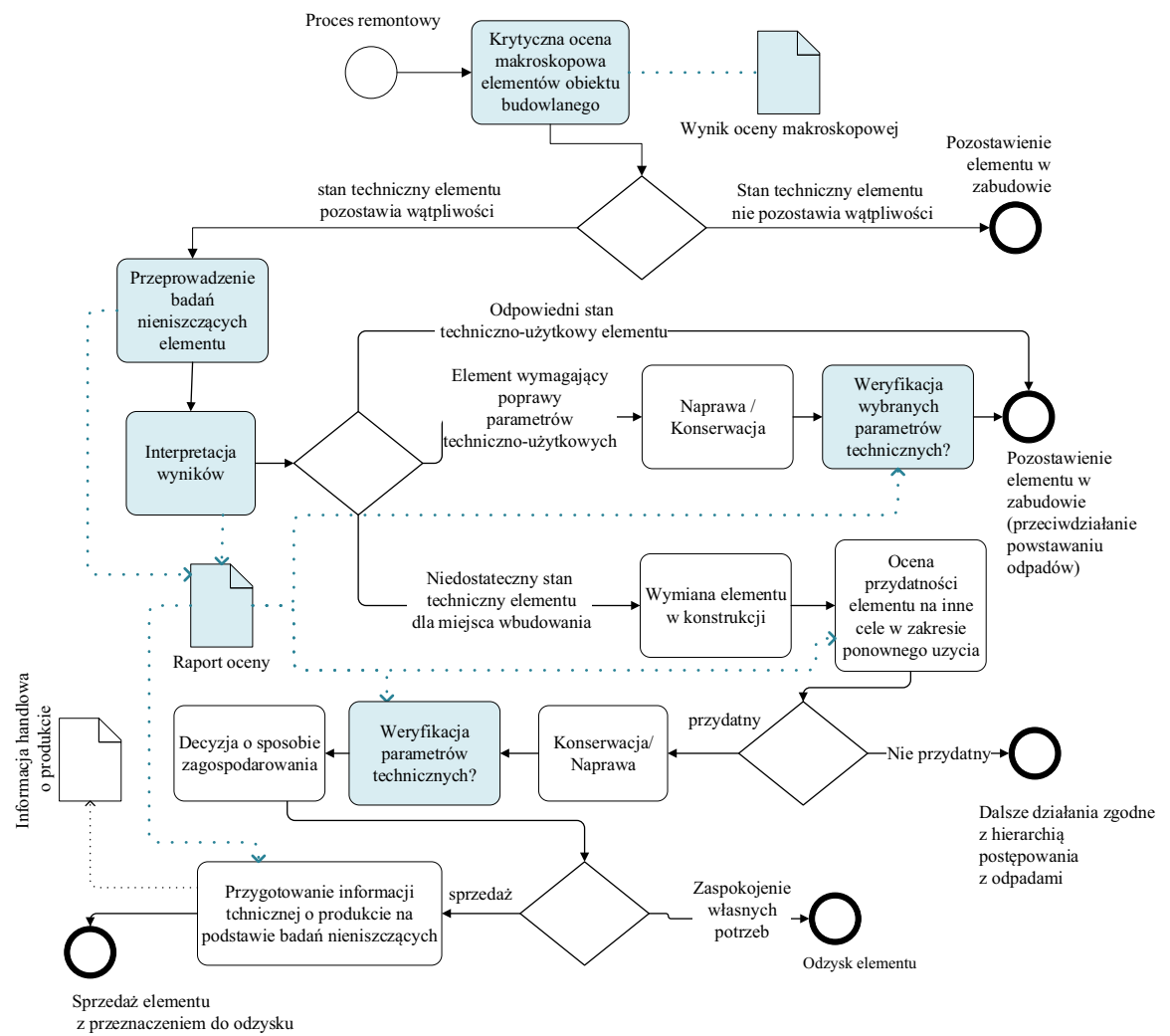

Rys.1. Schemat procesu gospodarowania odpadami z zastosowaniem metod NDT podczas remontu obiektu budowlanego

Przedstawione podejście do gospodarki odpadami budowlanymi ma następujące zalety: zapewnia gospodarkę odpadami zgodnie z hierarchią postępowania z odpadami; minimalizuje ryzyko związane z wystąpieniem awarii wynikającej z niewłaściwego oszacowania parametrów technicznych elementów budowlanych; umożliwia sprzedaż odzyskanego elementu z zapewnieniem jego jakości potwierdzonej wynikiem NDT; ocena parametrów technicznych może być prowadzona na placu budowy, co wiąże się z bezpośrednią sprzedażą a co za tym idzie redukcją kosztów i emisji związanych z transportem; pozwala na zachowanie autentyczności zabytkowych budynków.

Prezentowana koncepcja pomaga wyeliminować główne bariery związane z odzyskiwaniem odpadów w budownictwie, takie jak przekonanie konsumentów o niskiej jakości produktów z recyklingu [37], [38] oraz niepewność co do wyników odzysku [28], [37]. Wdrożenie i upowszechnienie oceny stanu technicznego odpadów to kluczowe elementy rozwoju efektywnych zwrotnych łańcuchów dostaw w sektorze budowlanym.

Received 28.08.2019,

Revised 28.10.2019 